\title{
Modus Vivendi Beyond the Social Contract: Peace, Justice, and Survival in Realist Political Theory
}

\author{
Thomas Fossen \\ Institute of Philosophy \\ Leiden University
}

Draft 05-01-2017

\begin{abstract}
This essay examines the promise of the notion of modus vivendi for realist political theory. I interpret recent theories of modus vivendi as affirming the priority of peace over justice, and explore several ways of making sense of this idea. I proceed to identify two key problems for modus vivendi theory, so conceived. Normatively speaking, it remains unclear how this approach can sustain a realist critique of Rawlsian theorizing about justice while avoiding a Hobbesian endorsement of absolutism. And conceptually, the theory remains wedded to a key feature of social contract theory: political order is conceived as based on agreement. This construes the horizontal tensions among individual or group agents in society as prior to the vertical, authoritative relations between authorities and their subjects. Political authority thereby appears from the start as a solution to societal conflict, rather than a problem in itself. I argue that this way of framing the issue abstracts from political experience. Instead I attempt to rethink the notion of modus vivendi from within the lived experience of political conflict, as oriented not primarily toward peace, but political survival. With this shift of perspective, the idea of modus vivendi shows us, pace Bernard Williams, that the "first political question" is not how to achieve order and stability, but rather: what can I live with?
\end{abstract}

Acknowledgments: For comments on earlier drafts, I would like to thank the participants of the conference "The Political Theory of Modus Vivendi" in Münster, especially the editors of this volume, as well as Tim Meijers, and my colleagues in the Conflict Reading Group: Razvan Ioan, James Pearson, Laura Pelegrin, Martine Prange, Herman Siemens, and Nicolás Vargas. Work on this article was supported by two grants from the Netherlands Organization for Scientific Research (NWO): "Between Deliberation and Agonism: Rethinking Conflict and its Relation to Law in Political Philosophy" and "Critical Moments: How do Events Affect how we Should Judge the Legitimacy of Political Authorities?"

\section{Introduction}

A good way of capturing the central thought of recent theories of modus vivendi is to say that a commitment to peace ought to take precedence over a commitment to justice. It is more important that we find some way of getting along without resorting 
to violence, than that we specify the terms according to which we do so in the morally right way (e.g. distributing the benefits of social cooperation, sorting out the rights and duties of citizens, setting up the best form of government, etc.). Modus vivendi theorists share with other proponents of realism in political theory a deep skepticism about the rational justification of moral principles, and about the possibility of practically achieving an overlapping consensus on a conception of justice a among diverse constituencies. ${ }^{1}$ In situations of tension or hostility among people with widely differing worldviews, striving for a way of living together in peace that does not require a consensus on justice seems a promisingly sober response - a realistic ideal, perhaps. $^{2}$

At one level, the importance of achieving and maintaining a modus vivendi seems clear. Bernard Williams famously considered achieving peace as the "first political question" since it is a "condition of solving, indeed posing, any others" (Williams 2005, 3). Still, even if we grant that peace is a precondition for justice, this hardly qualifies modus vivendi theory as an alterative to a theory of justice, for who would want to deny that peace is important? Couldn't we see peace as a steppingstone towards a just society, and the theory of modus vivendi as a non-ideal complement to an ideal theory of justice? Realists typically look to modus vivendi for an alternative, not a complement, to prevailing theories of justice. But it is not immediately apparent whether and how the notion is able to fulfill that role.

This essay probes promise of modus vivendi as a distinctively realist political theory by examining its normative commitments and conceptual presuppositions. To

\footnotetext{
${ }^{1}$ For helpful overviews of realism, see Baderin (2014), Galston (2010), and Rossi and Sleat (2014).

${ }^{2}$ Theories of modus vivendi have been endorsed in one form or another by Horton (2010), Gray (2000), McCabe (2010), and Neal (1999). In a similar vein, see Geuss (2008, 21-23). For recent discussions see also Wendt (2013b), Rossi (2010), Borgebund (2015), and Honig and Stears (2011).
} 
get a better grip on the theory of modus vivendi, we'll first need to examine more closely in what sense peace is supposed to have priority over justice, and why (section 2). As we'll quickly see, not just any state of non-violence will count as a modus vivendi: peace needs to be qualified in some suitable way, if the theory of modus vivendi is to stay shy of a Hobbesian endorsement of absolutism (section 3). But it remains unclear how peace is to be qualified without engaging in the kind of normative-theoretical enterprise that realists take to be so problematic.

The problem is compounded when we consider (in section 4) the conception of politics espoused in theories of modus vivendi. I'll argue that there is a structural similarity between modus vivendi theory and the social contract tradition in the sense that political order is conceived as resting on an agreement. As such it construes the horizontal tensions among individuals or groups in society as prior to, and in some sense legitimating or constituting, the vertical, hierarchical and authoritative relations between authorities and their subjects. This frames political authority as a solution to societal conflict rather than a problem in itself. While social contract theorists may have had good reasons to make such a move of abstraction from political experience, for modus vivendi theorists it poses a significant challenge to the realist credentials of their theory.

Rather than ending on this skeptical note, the final section presents, in a cursory manner, a way of understanding modus vivendi beyond the social contract. The idea of a modus vivendi does capture something important, but only when reconceived from within the lived experience of political conflict. I'll propose that we understand modus vivendi as not geared primarily toward peace, but political survival. With such a shift of perspective, the notion of modus vivendi shows us, pace 
Williams, that the first political question is not how to achieve order and stability. It is rather: what can I live with?

\section{The priority of peace over justice (or: contra Rawls)}

What is a modus vivendi, exactly? And what makes it particularly realistic? While definitions diverge somewhat, a first approximation is to say that it is a way of living together in peace under a common set of political institutions. But we'll need to work out more precisely what forms of conflict are ruled in or out by it - that is to say: what still counts as living together. For presumably modus vivendi does not imply the cessation of all political conflict. On the contrary, for realists, an appreciation of the conflict-ridden character of politics is a starting point for political theorizing. Conversely, a spiral of sectarian violence will clearly not count as a modus vivendi. Some forms of contestation will count as a breakdown of the modus vivendi, while others can be accommodated within it. But where to draw the line?

When John Rawls, who remains an anchor point for this discussion, deployed the notion of a "mere" modus vivendi in Political Liberalism, it was to provide a contrast for his own ideal of a "well-ordered society", a political community characterized by a thin moral consensus on a liberal conception of justice. Such an "overlapping consensus" does not preclude fundamental disagreement among worldviews, but it does require a limited, shared moral commitment to democratic institutions. In contrast, a modus vivendi is an agreement to abide by the rules of a political order that is "founded on a convergence of self- or group interests" (Rawls $2005,147)$. So what distinguishes a modus vivendi from a well-ordered society is the 
motivational basis for allegiance to the political order: self-interest rather than morality. The problem with this form of social order, according to Rawls, is that "social unity is only apparent, as its stability is contingent on circumstances remaining such as not to upset the fortunate convergence of interests" (Rawls 2005, 147). A genuine social unity requires "stability for the right reasons" (Rawls 2005, xxxix). For Rawls, we need a thin consensus on "constitutional essentials" in order to peacefully accommodate a reasonable pluralism of worldviews in the long term.

Skepticism about the feasibility, and indeed desirability, of such a consensus on justice has animated a revival of realist political thought, and some of these realists now seek to re-evaluate the notion of modus vivendi, albeit in a slightly different form. Like Rawlsian political liberalism, a modus vivendi excludes violent conflict among social groups by means of a shared allegiance to political authorities. For John Horton, for instance, "a modus vivendi should be understood as any political settlement that involves the preservation of peace and security and is generally acceptable to those who are party to it." (Horton 2010, 431) As such, it relies on shared allegiance to institutions that regulate conflicts, on willingness to engage in debate, to compromise, to accept the status quo at least for the time being, and, most important of all, on the refusal to resort to violence.

But in contrast to Rawls, modus vivendi theorists insist that a legitimate political order does not require a consensus on justice, not even a thin one. Still, that is not to say that a modus vivendi is founded on pure self-interest, to the exclusion of moral motivations. Rather, the idea is to broaden the range of acceptable grounds for assent. Enzo Rossi, for instance, characterizes a modus vivendi as

“an agreement establishing a stable political framework in which at least one but typically most - of the parties $[\ldots]$ participate for non-moral and non- 
epistemic reasons, i.e. (typically) prudential reasons, or for reasons that are not compatible with a liberal conception of citizenship." (Rossi 2010, 26)

And Horton suggests that "a modus vivendi can be arrived at by drawing on whatever resources - moral, intellectual, cultural, pragmatic, etc., as well as self-interest - are available in helping the parties to reach it" (Horton 2010, 439). So while political liberals and modus vivendi theorists both see a legitimate political order as being based on an agreement, the latter admit a much broader range of reasons for acceptance to underwrite such an agreement. ${ }^{3}$

While a modus vivendi does not require a shared conception of justice, it does require a shared allegiance to political order. Clearly, revolution or revolt against the authorities will count as a breach of the peace, as will sectarian violence. Indeed, the primary normative impetus of modus vivendi theory is to avoid precisely that: "modus vivendi is about seeking to avoid the kinds of evils that render practically impossible any worthwhile life". As such it is about "the avoidance of serious civil disruption and the maintenance of a level of social order that is at least sufficient to enable the parties subject to it to live minimally worthwhile lives" (Horton 2010, 438). Clearly, the qualification that lives ought to be worthwhile is important-we shall return to this below. The key point here is to see that we can characterize a modus vivendi as an agreement to endorse peace and political order, and to mutually refrain from jeopardizing those for the sake of realizing justice.

So the normative commitment at the heart of the theory of modus vivendi is the priority of peace over justice. Still, there are various ways in which this priority

\footnotetext{
${ }^{3}$ David McCabe has suggested to me that a modus vivendi does require some limited consensus on justice, in the sense that it involves people sharing a set of institutions and accepting the principles according to which those institutions operate. That sounds right. But what seems to me to be key in how Horton and Rossi distinguish modus vivendi from political liberalism is that the grounds of people's allegiance need not be considerations of justice; they do not have to agree because they see those principles as just.
} 
can be understood and justified, and these considerations dovetail with different views of what would make the theory "realistic". Let me briefly discuss three different arguments modus vivendi theorists have proposed to this effect: practical feasibility, normative validity, and political hazard.

It is easy to see that one might consider modus vivendi to be more realistic than a well-ordered society, in one sense of the word: simply in virtue of being less demanding, it has an edge of feasibility. ${ }^{4}$ A Rawlsian conception of justice needs to be justifiable in terms of widely diverging worldviews, while a modus vivendi does not face such a daunting task; presumably everyone has a basic interest in peace. Still, as mentioned at the outset, that in itself does not qualify modus vivendi as an alternative to a theory of justice. A stronger version of the feasibility concern claims that liberal consensus isn't just more difficult to achieve, but impossible: disagreement on justice is not a challenge to be overcome, but a "reality that political philosophy should accept" (Wendt 2013b, 575). If so, then striving for consensus on justice is fundamentally misguided. On this line of thinking, modus vivendi should be considered more realistic not because it is more easily achieved, but because it does not ask us to deny or wish away conditions of persistent pluralism and disagreement. ${ }^{5}$ Admittedly, for a Rawlsian concerned to achieve an overlapping consensus on justice, it would be a serious problem if doing so were impossible. But it is hard to know what is possible in advance. The mere suspicion of impossibility will provide little reason to keep from trying, and from what has been said so far, there seems little harm in that. Moreover, it is questionable whether the actual beliefs and motivational capacities of citizens pose a challenge to the normative validity of a theory of justice

\footnotetext{
${ }^{4}$ Although there is debate as to whether this is bought at the price of long-term stability, as Rawls objected. See Rawls (2005), Lynch (2009), and Wendt (2013b).

${ }^{5}$ In this vein, Rossi postulates the desideratum that consensus be "a concrete possibility something feasible given the citizenry's actual motives, beliefs, and desires" $(2010,30)$.
} 
(Estlund 2011). So I think that if modus vivendi theory is going to have a real sting against theories of justice, it needs to convince us that there is a trade-off between peace and justice, or even a problem with the idea of justice itself. Feasibility concerns alone will not do.

A different approach is to question the normative validity of a conception of justice. John Gray takes this line. He denies the validity of any single conception of justice on the grounds of value pluralism. Conceptions of justice are inherently connected with particular forms of life, of which there are many, none of which is rationally privileged over the others (Gray 2000). Others, such as Horton, take a more agnostic approach. They argue for a commitment to peace rather than justice because it avoids contentious moral commitments. There may well be a truth about justice, but it may not be politically prudent, or even ethical, to take one's conception of that truth as decisive in a context of deep disagreement. Thus Horton considers one of the merits of modus vivendi theory to be that it avoids "preconceived, philosophically favoured standards of fairness or justice" (Horton 2010, 438). The realist inclinations of modus vivendi theorists here take the form of a moral-theoretical abstinence. I'll discuss below whether modus vivendi theorists can avoid engaging theories of justice on their own turf in this way.

The third way of articulating the priority of peace over justice is to say that focusing too much on getting it right threatens our very getting along in peace. If that is true, then arguably even those who find themselves in a society that has achieved (provisional) peace in the form of a modus vivendi should settle for that rather than strive for a fully just society. Fabian Wendt's gloss on modus vivendi as “compromising on justice" captures this sentiment nicely (Wendt 2013a). The point seems to be implied also by Horton: 
"Modus vivendi is not an inspiring ideal. It lacks the theoretical glamour (and moral self-righteousness) of more ambitious forms of liberal theory. But in a world where civil disorder and violence are much more likely a prospect than the realisation of our highest ideals, even when we know what they are, there is much to be said for it." (Horton 2006, 167)

Horton doesn't go so far as to say that striving for the "realisation of our highest ideals" is the cause of "civil disorder and violence" but it is not hard to see how an argument to that effect could provide strong support for a politics of modus vivendi. At present, however, modus vivendi theorists have done little to make it plausible that political order is so precarious that striving for a consensus on justice is so hazardous as to jeopardize the peace.

\section{Qualifying peace (or: contra Hobbes)}

At this stage, the question arises how the theory of modus vivendi relates to that more distant giant of the social contract tradition, Thomas Hobbes. For Hobbes's absolutist defense of sovereignty could be seen as the archetype of a theory that prioritizes peace over justice. Everyone's judging for him- or herself what is right is a perennial cause of discord and civil war. The only solution is for each individual to concede the right to judge to the sovereign. It is for the sovereign to determine what will count as just; independent judgment by subjects is an immediate threat to the peace: "It belongeth therefore to him that hath the Soveraign Power, to be Judge, or constitute all Judges of Opinions and Doctrines, as a thing necessary to Peace; therby to prevent Discord and Civill Warre.” (Hobbes 2012, 2:272) 
Would current theories of modus vivendi, like Hobbes, prescribe submission to any moderately effective sovereign? The answer is clearly no: modus vivendi theorists typically do not think one ought to settle for just any status quo arrangement. While avoiding violent struggle is of prime importance, not just any state of nonviolence will count as a modus vivendi. ${ }^{6}$ The crux of modus vivendi as an ideal is that of a qualified peace. But qualified in what sense? Hobbes's answer seems clear enough: as long as the sovereign does not pose an immediate threat to your physical integrity, you ought to obey for the sake of preserving the peace. Modus vivendi theorists differ in the ways in which they seek to avoid the absolutist implications of Hobbes's line of reasoning. Let me briefly canvass three versions of the theory, beginning with that of John Gray.

For Gray, what distinguishes a modus vivendi from just any stable political order is that it is inclusive of pluralism. In his view, both absolute monarchs and political liberals rely (to different degrees) on the suppression or exclusion of forms of life that do not fit the mold. Modus vivendi presses the envelope of pluralism to allow a broader range of forms of life to flourish. ${ }^{7}$

"The aim of modus vivendi cannot be to still the conflict of values. It is to reconcile individuals and ways of life honouring conflicting values to a life in common. We do not need common values in order to live together in peace. We need common institutions in which many forms of life can coexist." (Gray 2000, 6)

\footnotetext{
${ }^{6}$ According to Horton "there is nothing in the theory [of modus vivendi] that implies that [peace and security] must always or of necessity outweigh all other goods." $(2010,444)$. 7 "Modus vivendi continues the liberal search for peaceful coexistence; but it does so by giving up the belief that one way of life, or a single type of regime, could be best for all." (Gray 2000, 139)
} 
It is not clear exactly what sort of institutional framework Gray has in mind that would deliver both stability and inclusiveness, or how far it would diverge in practice from liberal proposals. What is clear is that this pluralism is in itself a demanding political ideal. Gray's commitment to inclusion of different cultures is motivated by his commitment to value pluralism. And, as Horton has argued, this value pluralism is in itself a contentious ethical doctrine (Horton 2006). It seems, then, that qualifying peace in this way presses Gray onto the terrain of a philosophical dispute about the validity of (meta-)ethical doctrines that he no longer sees as viable. ${ }^{8}$

As a second example, consider Fabian Wendt's ideal of "ambitious peace" (Wendt 2013b). Assuming the impossibility of a consensus on justice, he claims that settling for just any status quo is simply too unattractive to be a compelling political ideal. "Peace, according to this ambitious conception, means the condition of nonviolent coexistence among morally divided groups, based on arrangements that allow every freely associated group to live according to conscience without any external interference." (Wendt 2013b, 582; building on Kukathas 2003) Wendt's proposal is akin to Gray's in that it seeks to include a wider range of differing conceptions of justice. What is distinctive is his idea that this requires minimal state interference to allow for maximal freedom of conscience. Yet, despite Wendt's insistence to the contrary, it is difficult to accept that this proposal does not itself rely on a specific, contestable view of justice. ${ }^{9}$ Indeed, Wendt himself argues that ambitious peace

\footnotetext{
${ }^{8}$ For more in-depth discussions of Gray's proposal, see Gaus (2003, 56-67) and Horton (2006). A similar view to Gray's can be found in McCabe (2010), see Borgebund (2015) for a discussion.

${ }^{9}$ Wendt anticipates this objection. His reply is that "[i]t is not a conception of justice because it claims that every freely associated group of persons should be able to live according to its own conception of justice without external interference. Like ordinary peace, ambitious peace means stable, non-violent coexistence that does not presuppose a consensus on justice or any other first-order, substantive moral ideas." (2013b, 588) But I do not understand why what Wendt calls "second-order" moral commitments would not constitute a conception of justice, nor why his negative conception of freedom and his distinction between the "internal" and
} 
requires a moral consensus, pointing out that "the idea that we should abide by norms which tolerate moral disagreement is itself a moral proposition" (Wendt 2013b, 587). So just like Gray, Wendt cannot get around the commitment to engage in a normativetheoretical justificatory project, and thus to engage with liberal theory on its terms. What results may be a different theory from political liberalism, but it is not a more realistic, less moralistic form of theorizing.

Matters are a bit more complicated in the case of Horton. ${ }^{10}$ As we've seen he wants to dodge the demand for philosophical justification by avoiding contentious moral commitments. Still, he too endorses a qualification on peace, because "[a] peaceful situation preserved entirely through suppression or tyranny, or at the extreme by the exclusion or even elimination of those who do not accept it, is not a modus vivendi" (Horton 2010, 439). His qualification is that the modus vivendi arrangement be "broadly accepted by" or "generally acceptable to" those involved. Horton appears hesitant about how exactly this acceptance or acceptability requirement is to be understood. He points out that any demanding way of cashing it out, to the effect that the political order must be normatively justified to all subjected to it, would be at odds with the "realist spirit" of modus vivendi (Horton 2010, 439). What is to count as acceptable, and why, is not for the theorist to determine, but for participants to sort out in practice: "there is no good reason to think that the appropriate content of any modus vivendi can be determined in advance, for example by political theorists, of the workings of the political process itself" (Horton 2010, 439). Nor does Horton seek to theoretically spell out, in a Habermasian vein, the conditions under which people are to sort this out for themselves, if the outcome of the political process is to count as

\footnotetext{
"external" affairs of groups would be less contentious and in need justification than the conceptions of justice he aims to avoid.

${ }^{10}$ It should be noted that Horton's endorsement of modus vivendi seems rather tentative, acknowledging that it faces many challenges. For the sake of argument, let us treat him as less ambivalent than he is.
} 
acceptable - except to say that it cannot be the product of blatant manipulation, coercion, or violence.

It seems plausible enough to say that an agreement brought about through manipulation, coercion, or violence is no genuine modus vivendi. But it is hard to see how a modus vivendi can be distinguished from a Hobbesian peace, without appealing to stronger normative commitments as to the content of such an agreement or the process through which it is to be reached. After all, acceptance is a condition for peace also for Hobbes. It is just that for Hobbes fear and the threat of violence do not make such an agreement any less valid or acceptable. If one wants to say that a genuine modus vivendi involves more than absence of resistance on the part of subjects (whether induced by fear or otherwise), and the absence of the structural exercise (but not the threat) of violence by the authorities, then it seems that more needs to be said about the sense of voluntariness or acceptability required. In fairness, Horton is well aware of the difficulty $(2010,442-44)$. But I don't see how it can be addressed without engaging in the kind of normative debate that Horton wishes to avoid.

To conclude, for now: modus vivendi theory sits unstably between Rawls and Hobbes. It can avoid a Hobbesian endorsement of just any stable order by saying that only a suitably qualified peace counts as a modus vivendi. But doing so also raises precisely the kind of demand for normative justification that realists typically refuse to engage in. It seems that peace can only be qualified in the sense required here by bringing in substantial normative commitments and engaging theorists of justice on their own turf. 


\section{Remains of the social contract}

I think there is a deeper obstacle to the viability of modus vivendi theory as a distinctively realist alternative to Hobbesian absolutism and Rawlsian theorizing about justice. To explain this, I want to shift gears now and focus on the conceptual presuppositions of the theory, rather than its normative commitments.

As we've seen, the notion of agreement is central to modus vivendi theory, so some theorists have with good reason framed it as a form of social contract theory (e.g. Wendt 2013b, 575). At the same time, there is a sense in which it differs significantly from the contract tradition. The hallmark of social contract theory is a deliberate move of abstraction, away from lived political experience, through some “device of representation," as Rawls aptly calls it (Rawls 2005, 25-27) — be it a State of Nature or an Original Position. Abstracting from our immediate political experience is supposed to enable us to question the political order from an impartial moral or rational point of view. The state of nature helps us to abstract from disagreements arising from contingent, morally arbitrary characteristics of agents, from pathological forms of socialization, or from the very forms of authority that we are calling into question. Hobbes asks us to imagine a situation devoid of any political authority so that we can see the violent conflict to which man is naturally inclined and exposed and thereby feel the full force of the line of thinking that leads him, and should induce us, to endorse absolute authority. And Rawls's "veil of ignorance" invites us to abstract from those contingent features of our social existence that would arbitrarily color our judgment of what a well-ordered society would look like. In both cases, the device of representation transports us outside of our selves, by means of the imagination, to a vantage point not encumbered by the immediate political relations in 
which we find ourselves. In that sense, the social contract approach asks us to adopt a third-personal perspective on our first- and second-personal political relations.

From a realist point of view, the idea that we can adopt a standpoint outside of political relations from which we can impartially settle questions of justice or legitimacy is highly problematic. For realists, political theorizing should remain closely tied to political experience. In this vein, it is typically regarded as an advantage of modus vivendi theory that it does not rely on an abstraction like the State of Nature or the Original Position, but is rooted rather less imaginatively in the acknowledgment of pluralism and disagreement as encountered in political reality.

Nonetheless, as we've seen, modus vivendi is still conceived as an agreement to accept the political order and to mutually refrain from breaking the peace for the sake of justice. Thus there remains a crucial structural similarity between modus vivendi and other forms of contract theory, in that the authorities appear in first instance as the object of an agreement among social groups or individuals. The authorities themselves are, like Hobbes' sovereign, not parties to the agreement. So like other forms of social contract theory, modus vivendi relies on a conception of politics in which horizontal relations of interaction among social agents are in some sense primary or original, whereas the vertical relations of subjects to authorities are secondary or derived. Political reality is at bottom a matter of conflict among individuals or groups; only in second instance does political authority appear-and when it does appear, it is mainly as a solution to the problem. Basic political institutions themselves are in this sense above the fray. Modus vivendi theorists will acknowledge, of course, that institutional arrangements may themselves be the object of disagreement and contestation, within measure; but, importantly, they cannot radically be called into question without threatening to break the peace, which would 
result in the disruption of order that the theory intends to avoid. Modus vivendi theory thus reproduces and depends upon social contract theory's neat association of the authorities with peace, order, and stability; and the alternative with war, disorder, and anarchy.

This observation does not in itself constitute an objection, of course. On the contrary, it situates the theory of modus vivendi in the context of a venerable tradition. But taking seriously that it is a form of contract theory, because it construes order as resting on agreement, helps to bring out a tension with modus vivendi theorists' commitment to realism, at least in what seems to me the most appealing sense of the word. Realism in that sense means taking the phenomenology of politics seriously. Crudely put, it is to grasp questions and phenomena as they manifest themself in political experience. The question now is whether the conceptual schema inherited from the contract tradition, in which political order is grounded on a prior agreement, does justice to the lived experience of political conflict.

So far, we have assumed, along with the theorists under consideration, that the primary political problem to which modus vivendi is supposed to be a solution is pluralism and disagreement among the individuals or groups that make up a society. If that is the problem, then it seems natural to view the authorities as the solution to this primordial conflict; not by resolving conflict once and for all, but certainly restraining it. But what prevents the authorities themselves from being implicated in the problem from the start? What if the authorities charged with keeping the peace are themselves a source of oppression and injustice?

From the first-person point of view of someone immersed in a political situation, the conception of politics according to which the vertical relation of subject and authority is secondary to a relation among conflicting groups or individuals is 
itself an abstraction, at which one can only arrive by stepping out of one's situated perspective and postulating an external, observer's point of view—precisely the kind of move of abstraction characteristic of contract theory. We find ourselves not simply among a plurality of others with possibly competing interests and conflicting values and principles; we typically already find ourselves confronted with authorities that exercise power and make claims on us. That is to say, the question of how to live with the authorities is as primordial, and often as practically pressing, as the question of how to get along with other individuals and social groups.

In fact, authorities often have a far more problematic relation to seemingly horizontal inter-group conflict than the neat opposition between order and conflict suggests. Such a neat opposition is of course frequently invoked by the authorities themselves, especially when they are under pressure. Take, for instance, the reaction of Hosni Mubarak to the demonstrations aimed at toppling his regime, in early 2011:

"Those protests were transformed from a noble and civilised phenomenon of practising freedom of expression to unfortunate clashes, mobilised and controlled by political forces that wanted to escalate and worsen the situation. They targeted the nation's security and stability through acts of provocation, theft and looting and setting fires and blocking roads and attacking vital installations and public and private properties and storming some diplomatic missions. [...] The events of the last few days require us all as a people and as a leadership to choose between chaos and stability [...]" (Reuters 2011)

Mubarak offered a choice between the stability that results from submission to the authorities, and the chaos that would prevail in their absence. But that was of course not an entirely accurate picture. Although it was true that violence resulted when the protests continued, that was at least as much the consequence of deliberate agency on 
the part of the regime as of its incapacitation. Violence resulted largely because the authorities responded to protest with a campaign of intimidation. ${ }^{11}$ It is no law of nature that opposition and protest, even revolution, leads to chaos and violence; it all depends on the dynamics of action and reaction in which the authorities themselves are just as much involved. The specter of sectarian violence that is raised as soon as one calls the authorities into question may seem validated by the experience of the countries where the Arab uprising degenerated into a horrific winter. But we should beware of seeing necessity at work in these outcomes, and not be oblivious to the extent to which authorities themselves brought about or facilitated the degeneration into sectarian conflict and civil war.

Of this blackmail of the social contract, the theory of modus vivendi offers no adequate diagnosis. It is not that modus vivendi theorists picture the authorities as implausibly benevolent. To be sure, any realist would acknowledge that political order relies on some degree of violence and coercion. The point is that this vertical violence and coercion is framed as a response to, and legitimated in terms of, the supposedly more primordial horizontal tension and conflict between social groups. The latter is construed as prior in the sense that the parties to an agreement must precede the object of the agreement. This moment of abstraction obscures the ways in which authorities can be implicated in seemingly horizontal inter-group violence, conflict, and sectarian strife. The idea of an order resting on prior agreement among individuals or groups, inherited from the contract tradition, prevents modus vivendi

\footnotetext{
${ }^{11}$ A well-documented example is the infamous "battle of the camel" where pro-regime thugs charged onto the square riding camels and beating up protesters (Fathi 2012; Khalil 2012, 219-43).
} 
theory from problematizing this pervasive spatial metaphor, according to which the authorities stand above the fray of competing interests and values. ${ }^{12}$

Ironically, modus vivendi theory is worse off in this regard than the contract theories it seeks to overcome. Because it lacks anything analogous to the state of nature, the theory fails to acknowledge its move of abstraction from lived experience for what it is: a device of representation, a theoretical construct intended to tease out, test, and refine one's normative presuppositions. The realist aspirations of modus vivendi theory preclude appeal to such a heuristic device, and as a result the dichotomy of authority-guaranteed-peace versus anarchic conflict attains something like an ontological status in the theory - a status that is hard to square with political experience.

Perhaps this overstates the point. Horton's formulation of the theory, in particular, is highly nuanced, and he anticipates the line of criticism I've developed here. Indeed, Horton warns us not to think of modus vivendi in terms of a simple opposition between order and conflict. A modus vivendi is "never a definitive, once and for all, done deal: a modus vivendi is always an ongoing achievement, and to some degree potentially precarious and susceptible to being undermined by any of the infinite variety of life's contingencies." Thus, modus vivendi "must be continuously reaffirmed in practice, its legitimacy effectively reasserted, if only implicitly by remaining unchallenged." (Horton 2010, 440) Horton acknowledges that politics involves an ongoing and dynamic interplay between subjects and authorities, in which the legitimacy of those authorities can be called into question: "there will be times

\footnotetext{
${ }^{12}$ Bonnie Honig and Marc Stears make basically the same point about the realism of Raymond Geuss and, to a lesser degree, Bernard Williams: " [T] hey obscure the dangers of stabilisation, especially the moments in politics where the state seeks to reassure us that it is acting in the name of stability by marginalising the voices of those who feel the time is right for subversion because the terms of the current order's stability exact too high a cost for some" (Honig and Stears 2011, 202).
} 
when more fundamental or radical change will be the only way in which a failing modus vivendi can be repaired or a new one established." (Horton 2010, 440)

Clearly, then, Horton wants to resist the problematic dualism of order and conflict that I've attributed to modus vivendi theory. Still, the question remains whether he can consistently make sense of what it is to strive for or to contest a modus vivendi, from the perspective of participants. Let me approach the issue this way: Who is to decide when radical change is called for? Who is to say whether a modus vivendi is failing? For Horton, as we've seen, the answer is the parties themselves. This is not something that can be determined from an independent standpoint. But let us press this issue further. Let's say that you, as a participant, no longer find the terms of the current order acceptable, and you withdraw your acceptance from the status quo. Does your withdrawal now break an existing modus vivendi? Or is your withdrawal a response to a breakdown of the modus vivendi that has already occurred, perhaps because of unacceptable behavior on the part of the authorities? Does your withdrawal make it the case that there is in fact no longer a modus vivendi, or is it a consequence of that fact? And can one be mistaken about whether there is a modus vivendi in place?

My impression is that Horton's views in this regard are not always consistent. Some of his formulations imply that the existence of a modus vivendi is a matter of observable fact: when the parties accept the terms of the current order, there is a modus vivendi; when they refuse to, then not. "A modus vivendi exists only so long as the parties to it continue to accept it; when that ceases to be so, either renegotiation or coercion are pretty much the only options." (Horton 2010, 440-41) On this interpretation, if a party withdraws its acceptance, that makes it the case that a modus vivendi no longer exists. Determining whether a situation is a modus vivendi is a 
matter of giving an accurate description, from a third-person perspective, of the attitudes of the participants: whether or not they accept the existing order. But note that if the existence of a modus vivendi is strictly a matter of de facto acceptance, then there can be little meaningful political disagreement as to whether a modus vivendi is in place: if someone denies there is one, then that simply makes it so.

More often, however, Horton suggests that the existence of a modus vivendi is not such a clear-cut matter. For instance, at one point he allows that there may be "contested claims over whether a modus vivendi has been achieved." (Horton 2010, 443) Determining whether one is in a situation of modus vivendi is now a matter of political judgment; of saying whether this situation is acceptable or not, rather than of accurately describing the acceptance, or lack thereof, of participants. On this reading — which is inconsistent with the former — withholding your acceptance can be interpreted as a response to a breakdown of the modus vivendi on the part of the authorities. But if the existence of a modus vivendi can be subject to political disagreement in this way, from the first-person perspective of participants, then this is not adequately captured by Horton's third-personal definitions of what it is for a modus vivendi to exist.

At bottom, then, Horton's version of the theory manifests the basic problem I have tried to explain in this section: it relies on a move of abstraction from the lived experience of political conflict which, given its realist commitments, it cannot account for. In Horton's account, this move is masked by his tacit slides, back and forth, between first- and third-personal characterizations of what it is for a modus vivendi to exist, and (what is essentially the same problem) by his failure to consistently distinguish between (normative) acceptability and (de facto) acceptance. I think the best way to respond to these issues is not to choose one or the other of these 
formulations, nor to dismiss the idea of modus vivendi as incoherent, but to adjust the terms in which the question is posed, by re-interpreting the notion of modus vivendi.

\section{Living on}

The preceding section sought to show that modus vivendi theory remains wedded (albeit grudgingly) to a basic conceptual scheme inherited from the social contract tradition, which can no longer be taken for granted given its realist aspirations. But it would be hasty to give up on the notion of modus vivendi altogether. Rather, I propose we move away from a conception of modus vivendi as a third-personal category, and explicate its meaning from the first-personal, practical point of view. So far the discussion has been operating with a characterization of modus vivendi from an observer's third-personal point of view: a situation is characterized as a modus vivendi when a political order attains a certain level of acceptance from those subject to it, for the types of reasons deemed appropriate by the theorist. ${ }^{13}$ But what would striving for a modus vivendi mean from the perspective of a political agent, i.e. someone who finds him- or herself in a political situation, confronted with the question of what to do? Can we give an account of modus vivendi that is meaningful and intelligible from the first-person perspective of political actors? Here I can only offer some sketchy remarks.

The twist I propose is to see modus vivendi as geared not primarily toward peace, but survival: living on, politically. To take it that a political situation is a modus vivendi is to take it that one's survival qua political agent is secure. The

\footnotetext{
${ }^{13}$ As attested by the definitions of modus vivendi from Horton and Rossi, quoted in section 2.
} 
opposite is not conflict, as such, but existential crisis. In other words, to say that a situation is a modus vivendi is to express a political judgment, to the effect it is that is sufficiently acceptable to bear living on with: "whatever concerns I have, I will work within the terms of the current order to address them." Notice that this characterization is perspectival: different people may experience and judge a situation in different ways. Note also that political survival in this sense concerns the survival of who one is in relation to others, not merely one's physical existence. Any political situation ineluctably raises the question of who one is, implicitly or explicitly, and this question bears on one's composure vis-à-vis others, including the authorities. A moment of crisis poses this question in a way that fundamentally challenges one's self-understanding. It is in such moments that striving for a modus vivendi-a way of living on, politically—becomes pressing.

For example, imagine yourself subject to a regime that violates some of your most deeply held convictions; say that it systematically oppresses a minority. Suppose you are not yourself a member of the persecuted minority, so your physical survival is not immediately at stake. And suppose that the regime purports to act in the name of a community with which you strongly self-identify, so in effect the regime acts in your name as well. The point here is that the regime, because it acts in your name, constitutes a challenge to your practical self-understanding as a member of that community. Various responses are possible: you may find it imperative to engage in some form of resistance to the regime, possibly risking your physical survival; you may find that you need to revisit your membership of the community; or you may find out that your convictions weren't as deeply held as you thought. What is not possible (except perhaps through some form of cognitive dissonance) is to simply carry on 
with your prior self-conception intact. You are pressed to find some way of being able to live with yourself in relation to others, including the authorities.

Of course, in most circumstances peace is conducive to political survival. But the important point is to acknowledge that finding a way of living on in relation to others cannot simply be a matter of jointly submitting to the authorities and refraining from violent conflict. If we reconceive modus vivendi as oriented in first instance to surviving rather than peace and order, it is easy to see how a non-violent status quo might nonetheless not count, from a first person perspective, as a modus vivendi, or how a gradual regime change may at some point count as breaking the modus vivendi, even when social order has not broken down. The absence of "serious civil disruption" (Horton 2010, 438) cannot guarantee political survival; and political survival might, in exceptional circumstances, demand breaking the peace. ${ }^{14}$ So pace Williams, the first political question is not how to achieve peace and order. It is rather: what can I live with? Living or not living, in this sense, is no simple binary matter. It involves qualitative judgment on what counts as a life worth living. And in tragic situations survival may not be possible without compromising part of oneself. ${ }^{15}$

Instead of conceiving the authorities as an object of agreement, on this alternative conception of modus vivendi they remain more profoundly ambiguous: their legitimacy remains potentially in question, since the question of what one can live with always remains to be asked. Furthermore, this way of framing the issue broadens our temporal horizon from the specific moment of concluding or breaking the peace. Living on means attending also to what occurs after a settlement has been

\footnotetext{
${ }^{14}$ I take it that this is what Horton's acceptability criterion was meant to capture.

15 "The goal is to salvage from the wreckage of the situation enough narrative unity for the self to go on," to borrow a pertinent formulation from Bonnie Honig $(2009,5)$ In fact, Honig's remark is a gloss on Williams' moral philosophy, which raises a question of how the latter relates to his notion, in his political theory, of the "first political question".
} 
reached. A modus vivendi is not achieved when authorities are accepted; at most it is initiated. $^{16}$

Two concerns may arise at this point, from opposite directions. On the one hand, from the perspective of ideal theorists, this shift from peace to survival may seem to make the notion of modus vivendi even thinner and less attractive, because survival appears to be even less demanding an ideal than peace. After all, even violent social conflict rarely signifies imminent death, only the constant threat of it. Doesn't striving for survival set the bar too low? But as I propose to conceive it, surviving politically is not simply a matter of continuing in existence, but rather of judgment as to what counts as worth living. In other words, what is at stake is qualified survival. Conceived in this way, striving for a modus vivendi might demand making a stand against authorities that are broadly accepted by others. Sometimes the wager of peace for the sake of justice may be inevitable, in the interest of qualified survival. Of course, what counts as a life worth living is a question on which people disagree, and my reframing of the notion of modus vivendi says nothing about how such a judgment can be made. But it is not necessarily a less demanding ideal than peace.

In the light of this response, however, realists might object that what we have here is an invitation to reckless idealism that puts peace at risk for the sake of justice. Wasn't the point of the theory of modus vivendi precisely to avoid contentious claims about justice, and to affirm the priority of peace? But if my analysis is correct, a theory of modus vivendi conceived as oriented toward peace rather than justice runs into normative and conceptual difficulties. So I think a concern for justice cannot be construed as external to a convincing explication of what it means to strive for modus vivendi (at least insofar as a sense of justice figures in the question of what makes a

\footnotetext{
${ }^{16}$ Again, Honig eloquently articulates the point: "survival points us beyond moral choice to its aftermath" (Honig 2009, 7).
} 
life worth living). To acknowledge this is not to succumb to the temptations of ideal theory. Nothing I have said entails that the question of what one can live with can be definitively settled by moral theorizing. Nor does it entail that the matter is arbitrary or purely subjective. It is rather to acknowledge that this is an irreducibly political question. Besides, insofar as the realist spirit of modus vivendi theory is to avoid naiveté about a consensus on justice, that can certainly be captured by my perspectival reformulation of the notion (twisted beyond recognition as it may otherwise be). We may not come to share a single conception of justice, but it does not follow that a sense of justice will not play a significant role, from anyone's given perspective, in what one can live with.

To conclude: having started off by interpreting theories of modus vivendi as endorsing the priority of peace to justice, I have ended up by re-interpreting the notion of modus vivendi as oriented in first instance toward political survival, not peace. This shift implies that the opposite of modus vivendi is not conflict, but existential crisis. And it suggests that some sense of justice is internal to what it means to strive for a modus vivendi.

\section{References}

Baderin, Alice. 2014. "Two Forms of Realism in Political Theory.” European Journal of Political Theory 13 (2): 132-53.

Borgebund, Harald. 2015. "Review Article: Modus Vivendi versus Public Reason and Liberal Equality: Three Approaches to Liberal Democracy." Critical Review of International Social and Political Philosophy 18 (5): 564-75. 
Estlund, David. 2011. "Human Nature and the Limits (If Any) of Political Philosophy." Philosophy \& Public Affairs 39 (3): 207-37.

Fathi, Yasmine. 2012. "Egypt's 'Battle of the Camel': The Day the Tide Turned." Ahram Online. February 2. http://english.ahram.org.eg/News/33470.aspx.

Galston, William A. 2010. "Realism in Political Theory." European Journal of Political Theory 9 (4): 385-411.

Gaus, Gerald F. 2003. Contemporary Theories of Liberalism: Public Reason as a Post-Enlightenment Project. London: SAGE.

Geuss, Raymond. 2008. Philosophy and Real Politics. Princeton: Princeton University Press.

Gray, John. 2000. Two Faces of Liberalism. New York: The New Press.

Hobbes, Thomas. 2012. Leviathan. Edited by Noel Malcolm. Critical edition. Vol. 2. 3 vols. Oxford: Oxford University Press.

Honig, Bonnie. 2009. Emergency Politics: Paradox, Law, Democracy. Princeton: Princeton University Press.

Honig, Bonnie, and Marc Stears. 2011. "The New Realism: From Modus Vivendi to Justice.” In Political Philosophy versus History? Contextualism and Real Politics in Contemporary Political Thought, edited by Jonathan Floyd and Marc Stears, 177-205. Cambridge: Cambridge University Press.

Horton, John. 2006. "John Gray and the Political Theory of Modus Vivendi." Critical Review of International Social and Political Philosophy 9 (2): 155-69.

_. 2010. "Realism, Liberal Moralism and a Political Theory of Modus Vivendi." European Journal of Political Theory 9 (4): 431-48.

Khalil, Ashraf. 2012. Liberation Square: Inside the Egyptian Revolution and the Rebirth of a Nation. St. Martin's Press. 
Kukathas, Chandran. 2003. The Liberal Archipelago: A Theory of Diversity and Freedom. Oxford: Oxford University Press.

Lynch, Sterling. 2009. "The Fact of Diversity and Reasonable Pluralism.” Journal of Moral Philosophy 6 (1): 70-93.

McCabe, David. 2010. Modus Vivendi Liberalism: Theory and Practice. Cambridge: Cambridge University Press.

Neal, Patrick. 1999. Liberalism and Its Discontents. New York; Wantage: NYU Press.

Rawls, John. 2005. Political Liberalism. New York: Columbia University Press.

Reuters. 2011. “TEXT-President Mubarak’s Speech after Mass Protest,” February 1. http://www.reuters.com/article/2011/02/01/egypt-mubarak-speechidAFLDE7102JP20110201.

Rossi, Enzo. 2010. "Modus Vivendi, Consensus, and (Realist) Liberal Legitimacy." Public Reason: Journal of Political and Moral Philosophy 2 (2): 21-39.

Rossi, Enzo, and Matt Sleat. 2014. "Realism in Normative Political Theory." Philosophy Compass 9 (10): 689-701.

Wendt, Fabian. 2013a. "Introduction: Compromising on Justice.” Critical Review of International Social and Political Philosophy 16 (4): 475-80.

_. 2013b. "Peace beyond Compromise." Critical Review of International Social and Political Philosophy 16 (4): 573-93.

Williams, Bernard. 2005. In the Beginning Was the Deed: Realism and Moralism in Political Argument. Princeton: Princeton University Press. 